NIST Technical Note 2029

\title{
A Computable General Equilibrium Model of Cedar Rapids
}

Jennifer Helgeson

Juan Fung

Cheyney O'Fallon

David Webb

Harvey Cutler

This publication is available free of charge from: https://doi.org/10.6028/NIST.TN.2029

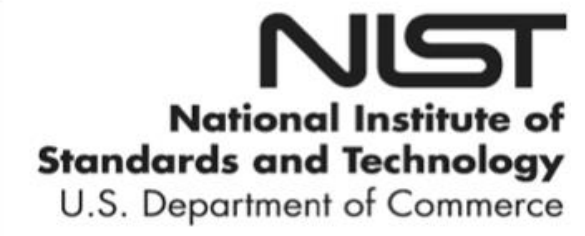


NIST Technical Note 2029

\title{
A Computable General Equilibrium Model of Cedar Rapids
}

\author{
Jennifer Helgeson \\ Juan Fung \\ Cheyney O'Fallon \\ David Webb \\ Applied Economics Office \\ Engineering Laboratory \\ Harvey Cutler \\ Department of Economics \\ Colorado State University
}

This publication is available free of charge from:

https://doi.org/10.6028/NIST.TN.2029

September 2018

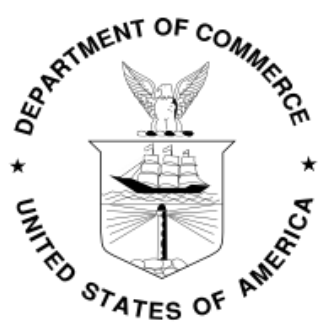

U.S. Department of Commerce

Wilbur L. Ross, Jr., Secretary

National Institute of Standards and Technology Walter Copan, NIST Director and Undersecretary of Commerce for Standards and Technology 
Certain commercial entities, equipment, or materials may be identified in this document in order to describe an experimental procedure or concept adequately. Such identification is not intended to imply recommendation or endorsement by the National Institute of Standards and Technology, nor is it intended to imply that the entities, materials, or equipment are necessarily the best available for the purpose.

National Institute of Standards and Technology Technical Note 2029 Natl. Inst. Stand. Technol. Tech. Note 2029, 25 pages (September 2018) CODEN: NTNOEF

This publication is available free of charge from: https://doi.org/10.6028/NIST.TN.2029 


\begin{abstract}
This report presents the development of a Computable General Equilibrium (CGE) model for the regional economy of Cedar Rapids, Iowa. The general approach that this case study takes is outlined in Helgeson et al. [1] as a method to quantify the net co-benefits of investing in increased resilience, or the "resilience dividend." The current report provides the background on Cedar Rapids as a case study in planning for increased resilience and provides an overview of the CGE model of Cedar Rapids at two different time periods. This report is intended to provide context and background for future applications of the Cedar Rapids CGE model to quantify the resilience dividend.
\end{abstract}

\title{
Key words
}

Resilience dividend, Community resilience, Flooding, Cedar Rapids, Computable General Equilibrium, CGE, Spatial. 


\section{Table of Contents}

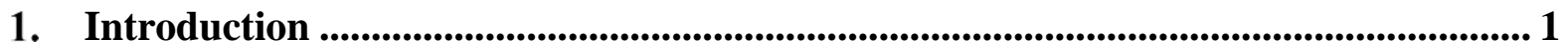

2. Background on the Resilience Dividend and the CGE Approach .............................. 2

2.1. The Importance of the Resilience Dividend ............................................................. 2

2.2. Defining and Quantifying the Resilience Dividend ............................................... 2

2.3. The CGE Approach to Quantifying the Resilience Dividend ................................. 3

3. Background on Cedar Rapids, Iowa ............................................................................. 5

3.1. The 2008 Midwestern Floods ......................................................................... 5

3.2. Recovery and the Road to Resilience in Cedar Rapids .......................................... 6

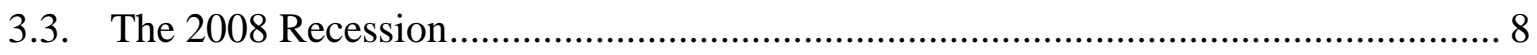

4. The Cedar Rapids CGE Models.......................................................................9

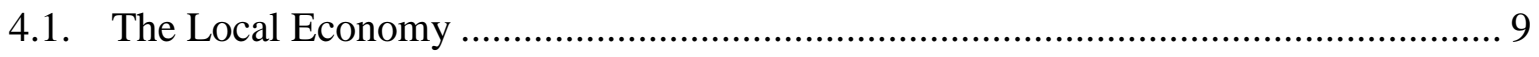

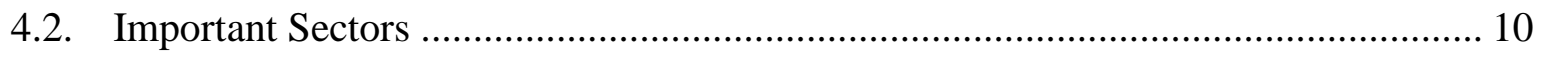

4.3. Downtown, NewBo, and Czech Village ......................................................... 12

4.4. Data Requirements and Other Details .......................................................... 14

5. Comparing Pre- and Post-2008 Cedar Rapids......................................................... 14

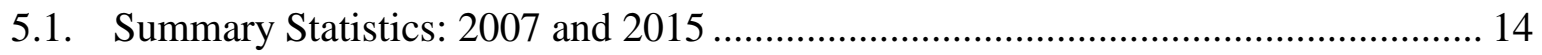

6. Summary and Next Steps: Quantifying the Resilience Dividend............................... 16

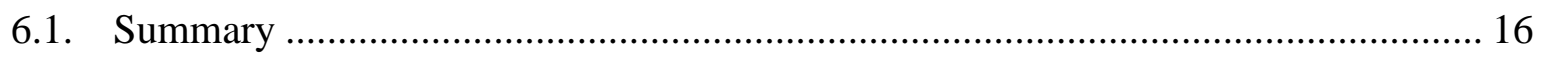

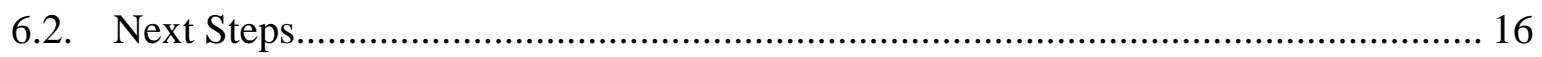

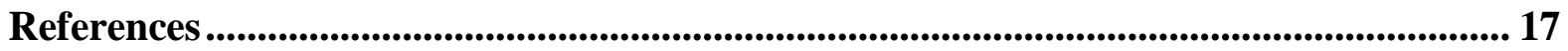




\section{List of Tables}

Table 1. Two-digit NAICS codes and industries for 2017. Source:

https://www.naics.com/search/.

Table 2. Sectors in the Cedar Rapids CGE models that are not present in downtown Cedar

Rapids.

Table 3. Sectors in the Cedar Rapids CGE models that are present within and outside downtown.

Table 4. Land and capital values (in millions of dollars) and total acres by district and year, based on County Assessor data for Linn County, IA.....

Table 5. Employment and (annual) wage per worker for Downtown and the rest of the regional economy by year, based on the Quarterly Census of Employment and Wages (QCEW) for the state of Iowa.

\section{List of Figures}

Figure 1. Schematic of main components in a CGE model. Note that ROW refers to the "Rest of the World", that is the aggregation of all economic transactions between the selected region under consideration and those not within the selected region.

Figure 2. Total precipitation during the period of June 1-15, 2008. Parts of Indiana, Illinois, Iowa, and Wisconsin received a foot or more of precipitation. Source: NOAA.

Figure 3. The Cedar River after the flood on June 12, 2008, with Downtown Cedar Rapids on the right ("East") side of the river and May's Island (with City Hall) in the center. Source: FEMA P-765 [15].

Figure 4. Extent of 2008 flood in Cedar Rapids, which exceed the 1-percent (100 year) and 0.2-percent (500 year) annual flood levels. Source: FEMA P-765 [15].

Figure 5. Demographic and economic statistics for the city of Cedar Rapids. Source: Cedar Rapids CAFR, Fiscal Year 2015 (FY15).

Figure 6. Principal employers in Cedar Rapids. Source: Cedar Rapids CAFR, FY15.......... 10 Figure 7. Detail of the "Downtown" area neighborhoods, with Czech Village and Downtown on the east side of the Cedar River and NewBo on the west. Map created using city of Cedar Rapids shapefiles (http://www.cedar-rapids.org/local_government/departments_g__v/information_technology/available_gis_data.php).. 


\section{Glossary}

BCA: Benefit-Cost Analysis

CAFR: Comprehensive Annual Financial Report

CGE: Computable General Equilibrium

DRM: Disaster Risk Management

GDP: Gross Domestic Product

LCA: Life-Cycle Analysis

NAICS: North American Industry Classification System

NPP: Cedar Rapids Neighborhood Planning Process

NPV: Net Present Value

ROW: Rest of the World

SAM: Social Accounting Matrix

SCGE: Spatial Computable General Equilibrium 


\section{Introduction}

As the number of large-scale disruptive natural events continues to rise, ${ }^{1}$ so do the associated losses. Kunreuther and Michel-Kerjan [3] find that costs of natural disaster-related losses jumped from $\$ 93.3$ billion in the 1960 s to $\$ 778.3$ billion in the 1990 s, while Strömberg [4] points out that population growth explains only about half of this increase. Communities need resilient strategies to reduce the impacts and losses from such disasters. However, this requires long-term investments with potentially negative return on investment if no disaster occurs within the planning horizon.

The resilience dividend, defined in Fung and Helgeson [5] as "the net benefit (or cost) that accrues, from investments aimed at increasing resilience, in the absence of a disruptive incident over the planning horizon," has the potential to change what benefits and costs are used to determine of return on investment. Accounting for "co-benefits," such as business growth and property value appreciation, allows long-term investments in resilience to be weighed against day-to-day benefits to the local economy even in the absence of a natural disaster.

This paper presents a Computable General Equilibrium (CGE) model approach to quantifying the resilience dividend. The methodology, as well as the importance of the resilience dividend, is described in detail in Helgeson et al. [1]. The CGE approach will be applied to modeling the regional economy of Cedar Rapids, Iowa, which has invested in increased resilience following an extreme flooding event in 2008, as discussed in more detail in Sec. 3. In addition to investing in a resilient flood-control system, a 20-year project that includes levees, removable walls, and new pump stations, ${ }^{2}$ the city of Cedar Rapids has also invested in revitalizing the downtown area. The motivation for revitalizing the downtown area is to have a more dynamic local economy that can absorb shocks, such as extreme flooding, more easily. Thus, in addition to making Cedar Rapids more resilient to natural disasters, revitalization of the downtown area also provides benefits for the local economy and social systems in the absence of a natural disaster.

The remainder of the report is organized as follows. Section 2 provides context for both the resilience dividend, popularized by Rodin [6], and the CGE approach to quantifying the resilience dividend introduced in Helgeson et al. [1]. Section 3 provides background on Cedar Rapids, including its experience with extreme flooding in 2008 and its subsequent investment in resilience. Section 4 presents the construction of two CGE models of Cedar Rapids: one is a snapshot of the economy in 2007-before the 2008 flood - and the other is a snapshot of the economy in 2015-seven years after the 2008 flood. Both models are spatial CGE models that capture the effects of economic shocks separately for the downtown area and the rest of the economy. Section 5 presents summary statistics from both models, comparing the pre- and post-2008 economies. Finally, Section 6 highlights next steps and future work to quantify the resilience dividend for Cedar Rapids.

\footnotetext{
${ }^{1}$ Schultz and Elliott [2], for instance, find that the number of such events has increased about five percent annually since 1960.

${ }^{2}$ See http://www.cedar-rapids.org/local government/departments g__ v/public works/cedar river flood_control system.php for an overview and progress report.
} 


\section{Background on the Resilience Dividend and the CGE Approach}

\subsection{The Importance of the Resilience Dividend}

Measuring the economic impact associated with resilience planning typically requires a better understanding of the costs and losses of natural disasters, including potentially cascading indirect losses. ${ }^{3}$ Economic valuation techniques, such as benefit-cost analyses (BCAs) and life-cycle analyses (LCAs), seldom capture the full range of costs and losses. Furthermore, accounting for uncertainty in estimates related to these costs and losses is complicated due to the nature and occurrence of disaster events.

Most importantly, measurement of net co-benefits (i.e., the resilience dividend) is needed to articulate the business case for resilience planning. Resilience actions that could alleviate vulnerability to a large-scale disruptive event may be seen as bad investments due to the low probability (or absence) of an event in a given time frame. Consideration of co-benefits (cocosts) is generally good practice, as the impacts of these values can be pivotal in identification of the most effective and efficient resilience plan. If quantification of cobenefits is possible, it should be included in the net-present valuation (NPV) of resilience plans; see Gilbert et al. [7] and Helgeson et al. [8].

Yet, much like cascading indirect losses from natural disasters, there are likely cascading and wide-spread effects of identified co-benefits. CGE models employ actual economic data from a community to simulate how its economy might react to changes in policy, technology, or other resilience planning initiatives. A particular strength of CGE models it that they can illustrate the distributive effects of net co-benefits. Spatial CGE (SCGE) models, in particular, can be used to distinguish flows throughout different areas of a community, which may vary in their vulnerability to and impacts from a disruptive event; see Helgeson et al. [1] for more details.

\subsection{Defining and Quantifying the Resilience Dividend}

In a review of the literature, Fung and Helgeson [5] found that co-benefits fall into three broad categories: 1. Objective-based, 2. Intent-based, and 3. Externality-based. ${ }^{4}$ The objective-based definition of co-benefits fits well into the methodology in this report. Objective-based definitions regard co-benefits as benefits to secondary objectives of a policy (ibid.). For instance, changed zoning in a community may have a primary objective of shifting commerce away from the flood zone, while secondary objectives may include stimulating economic growth in an area of town that becomes favorable for re-locating businesses.

As noted in Fung and Helgeson [5], much of the research to date on co-benefits focuses on climate change mitigation and adaptation. Moreover, co-benefits of resilience planning are typically considered for developing countries. Finally, quantification of co-benefits is very limited. This is understandable, as it is difficult to determine the full range of co-benefits $e x$ ante, as in a BCA, and to fully track co-benefits flowing throughout an economy ex post, as

\footnotetext{
${ }^{3}$ To date, direct losses tend to be better documented.

${ }^{4}$ Externalities are defined by benefits (costs) that accrue to third parties. As such we treat them fundamentally different from values that are encompassed by the resilience dividend. For a discussion of externalities versus non-disaster related benefits (i.e., the resilience dividend), see Gilbert et al. [7] and Helgeson et al. [8].
} 
in CGE. Nevertheless, the CGE approach can provide a broad picture of how co-benefits are distributed throughout an economy.

The concept of the resilience dividend was popularized in Rodin [6], which presents examples from the real world to illustrate the idea and its value. A series of World Bank reports have presented the resilience dividend as arising from a "Triple Dividend of Resilience" largely relevant to disaster risk management (DRM) (see Tanner et al. [9] and Mechler et al. [10]). ${ }^{5}$

Bond et al. [11] describe a Resilience Dividend Valuation Model (RDVM) and present six case studies in the developing country context to illustrate. Note that Bond et al. [11] define the resilience dividend as "the difference in net benefits from a project developed with a resilience lens versus one that is not." This definition is much broader than the definition used in this paper (Fung and Helgeson [5]), which is concerned with net benefits above and beyond benefits expected to accrue directly to the goal of resilience to a disruptive event.

\subsection{The CGE Approach to Quantifying the Resilience Dividend}

This section provides a general overview of CGE and SCGE models, and their application to quantifying the resilience dividend.

Overall, the aim of the CGE approach in this paper is to approximate a community's regional economy at a particular point in time (e.g., a "snapshot" of the economy after investing in resilience), and to assess how the community responds to exogenous changes (or "shocks") to the economy relative to that particular point in time. This makes CGE models a reasonable choice for exploring the impacts of large disruptive events, such as recessions and natural disasters, on a community's economic activity, as well as the effects of resilience planning on dampening these impacts. ${ }^{6}$

A CGE model simulates the working of a market economy in which prices and quantities supplied and demanded adjust to clear all markets. The economy is said to be in equilibrium when markets clear. Figure 1 illustrates the typical relationships in the economy modeled by a CGE. Households maximize their welfare, firms maximize their profits, the government is assumed to have a balanced budget, and resources are limited and costly. Effectively, a CGE model specifies the expected behavior of optimizing consumers and producers; the community government (e.g., taxes) is included as an agent to capture transactions in the circular flow of income (Robinson et al. [12]). ${ }^{7}$

SCGE models allow for a geographic distribution of the impacts from shocks to an economy. Thus, SCGE models are a natural fit for exploring the distributive effects (in particular, the resilience dividend) of resilience planning against large-scale shocks across a community. Helgeson et al. [1] discuss the data requirements for CGE and SCGE models in detail.

\footnotetext{
${ }^{5}$ This triple bottom line consists of: 1 . avoided or reduced losses, in the event of a disruptive event occurring; 2 . increased economic resilience from reduced disaster risk; and 3. co-benefits for development.

${ }^{6}$ It is worth noting that CGE models are typically used to assess policy changes, such as increases in sales tax, where the policy change is the shock (Helgeson et al. [1]).

${ }^{7}$ The CGE model takes a Walrasian neoclassical general equilibrium approach - the main equations that need to maintain equilibrium are derived from constrained optimization of the neoclassical production and consumption functions. Producers operate at a level as to maximize profits (minimize costs). Production factors - labor, capital, and land - are paid in accordance with their respective marginal productivities. Consumers are assumed to be subject to budget constraints, but otherwise maximize their utility. At equilibrium, the model solution at equilibrium provides a set of prices to clear commodity and factor markets within the modelled community's economy (see Bandara [13]).
} 


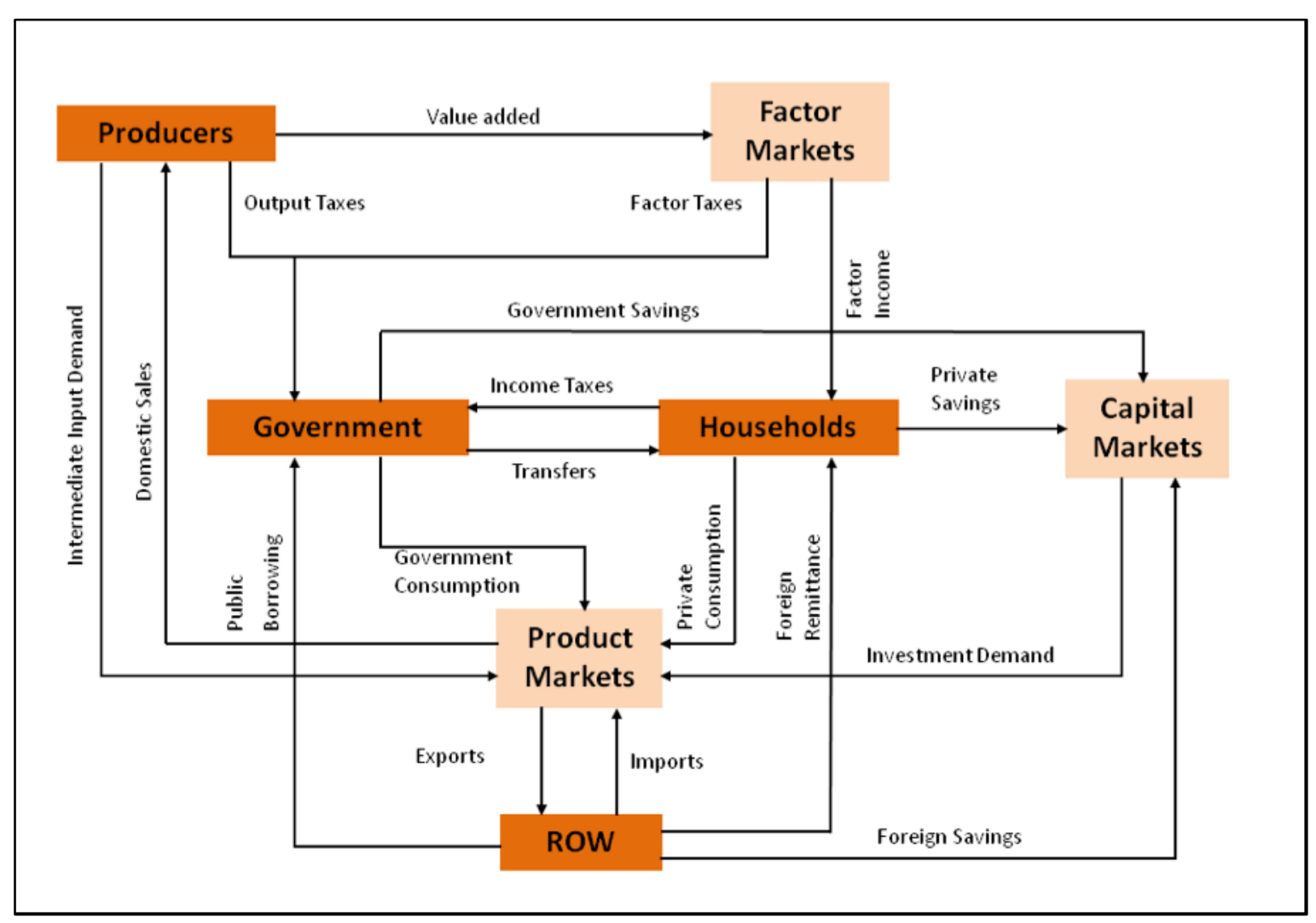

Figure 1. Schematic of main components in a CGE model. Note that ROW refers to the "Rest of the World", that is the aggregation of all economic transactions between the selected region under consideration and those not within the selected region.

This report uses a comparative-static (spatial) CGE modeling approach. Comparative-static approaches compare two alternative equilibria in order to assess the impact of shocks to the economy. ${ }^{8}$ Each equilibrium may be thought of as a state of the world (e.g., before or after a natural disaster). The process of adjustment from the old equilibrium to the new equilibrium is not explicitly represented in such a model, as the temporal element of a CGE model is not well defined. ${ }^{9}$ Nevertheless, the difference between the two states of the world is attributed solely to the shock and thus, impacts of the shock are quantified through changes to prices and quantities.

In some cases, the data required for a CGE model may be available for many periods, potentially providing snapshots of the economy at various points in time. In such cases, it may be possible to create one CGE model to capture the economy without (or with less) resilience and another CGE model that captures the economy with (or with more) resilience, providing plausible counterfactuals for quantifying the resilience dividend. In particular, if each economy responds to the same shock in different ways, the differences can be attributed to investing in resilience.

\footnotetext{
${ }^{8}$ In contrast, dynamic CGE models explicitly trace each model variable through time in order to capture the path to equilibrium (Pereira and Shove [14]). Helgeson et al. [1] discuss the potential difficulties with this approach.

${ }^{9}$ However, it is possible to distinguish between short-run and long-run equilibria (e.g., looking at whether capital stocks are allowed to adjust in a given run of the model).
} 
This report uses annual data to build two snapshots of the Cedar Rapids regional economy: one in 2007, before the floods, and the other in 2015, after the floods and some initial resilience investments. Each snapshot is assumed to be an equilibrium, hence may be thought of as alternative states of the world. Differences between these two equilibria will provide a baseline for grounding differential responses to shocks.

\section{Background on Cedar Rapids, Iowa}

\subsection{The 2008 Midwestern Floods}

In June 2008, heavy rainfall combined with oversaturated soils, resulting from extended snowfall from the preceding winter, to overflow rivers and streams throughout the Midwestern United States (FEMA P-765 [15]), as shown in Fig. 2. Iowa was hit particularly hard, with rivers breaching levees in Cedar Rapids, Des Moines, and Iowa City. A presidential disaster declaration for tornadoes and severe storms in Iowa, issued on May 27, 2008 for four counties, was amended after the floods to include 85 of Iowa's 99 counties (FEMA DR-1763 [16]).

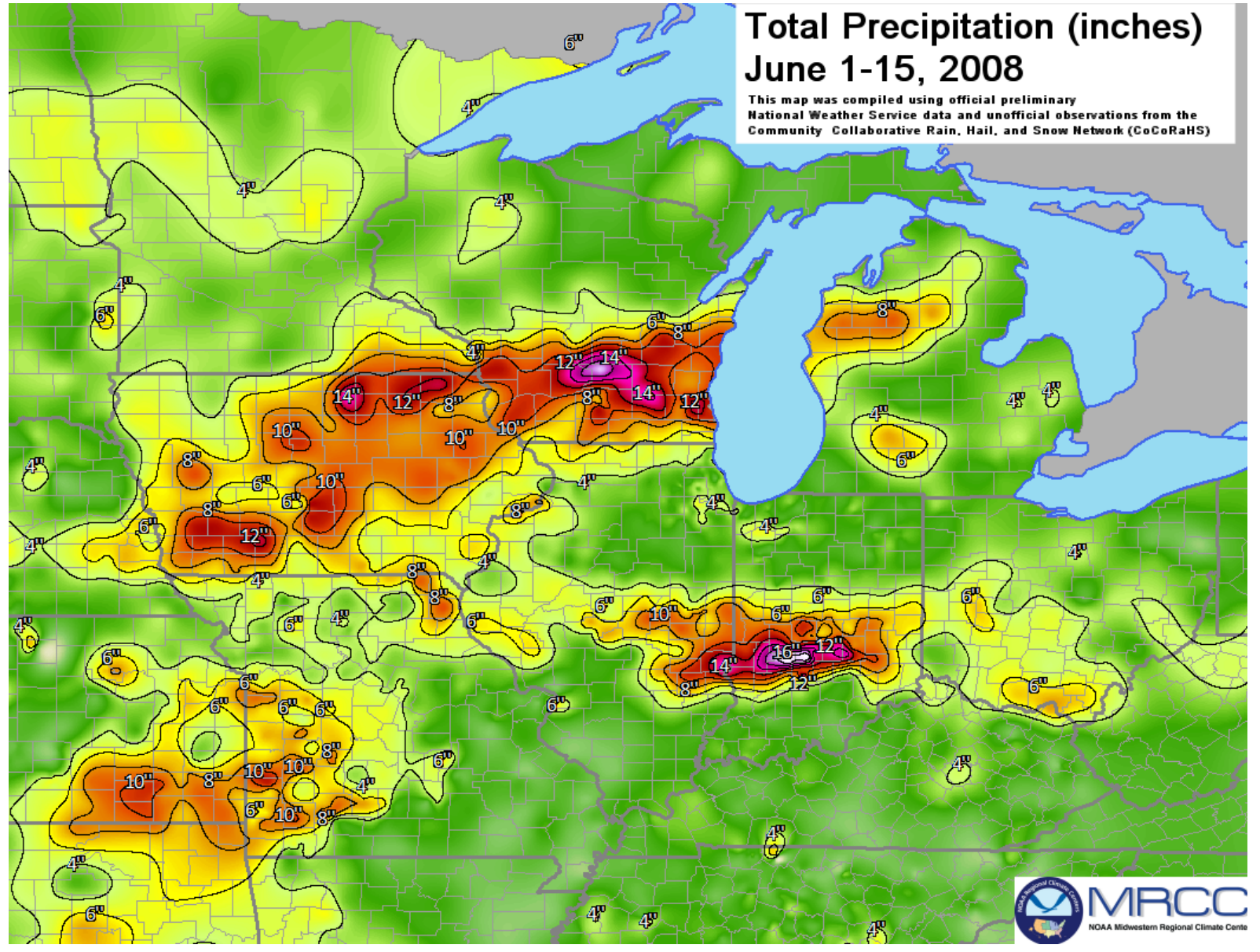

Figure 2. Total precipitation during the period of June 1-15, 2008. Parts of Indiana, Illinois, Iowa, and Wisconsin received a foot or more of precipitation. Source: NOAA. 
The Cedar River in Cedar Rapids, which runs roughly from the northwest of the city to its southeast, crested at 31.12 feet on June 12, 2008. This level was almost 12 feet higher than the previous record of 19.66 feet set in 1961 and 20 feet above flood stage, exceeding the 500-year floodplain area [15].

The city closed all bridges and evacuated the downtown area, resulting in zero flood-related fatalities. Nevertheless, the city experienced a total of $\$ 5.4$ billion in damages and economic losses [15]. The flooding affected an estimated at 10 square miles (or $14 \%$ of the city), including 1126 city blocks, nearly 5400 homes, over 800 commercial and government buildings, and displaced an estimated 18000 people. ${ }^{10}$ The areas near the river experienced the worst impacts, including the downtown area on the east side of river, home to several government buildings (such as City Hall, which is actually located in the river on May's Island, as shown in Fig. 3), and a largely residential area along the west side of the river.

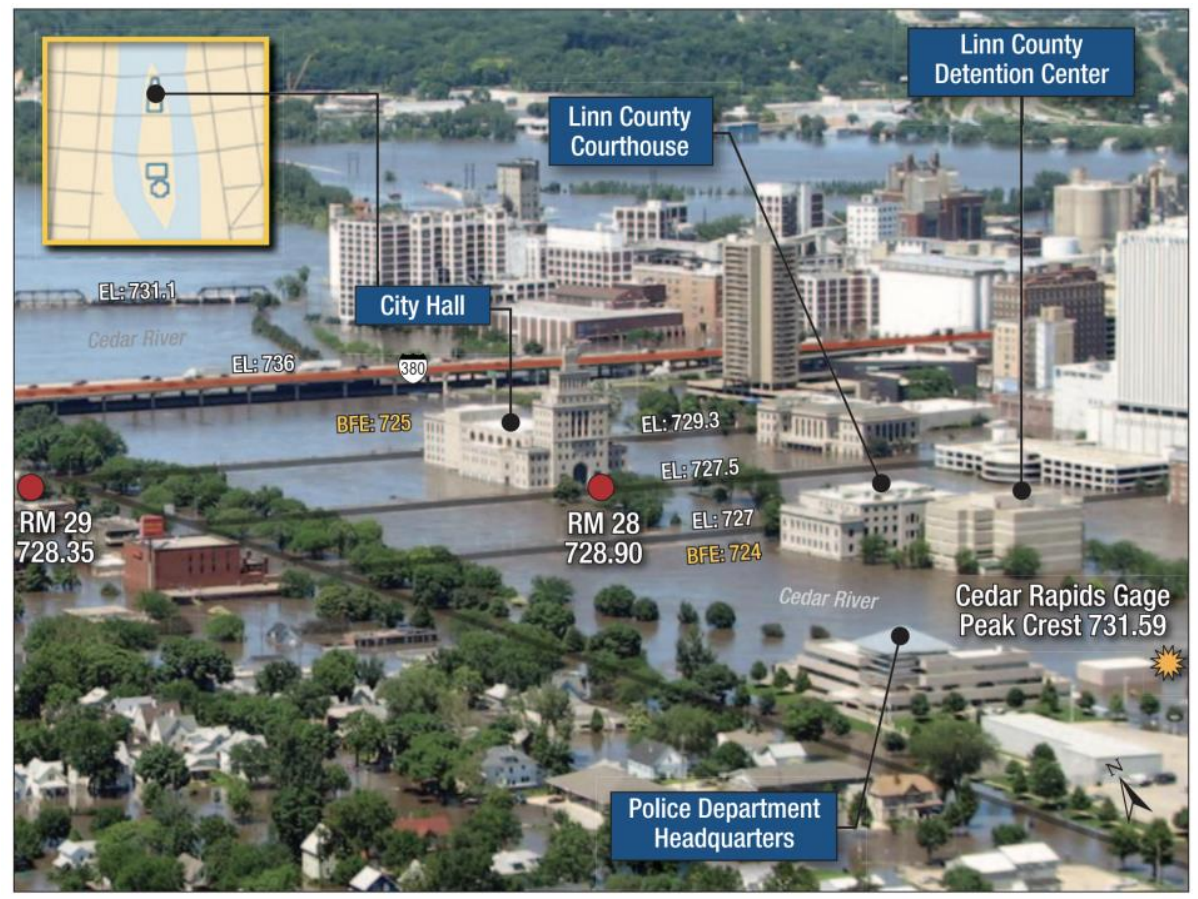

Figure 3. The Cedar River after the flood on June 12, 2008, with Downtown Cedar Rapids on the right ("East") side of the river and May's Island (with City Hall) in the center. Source: FEMA P-765 [15].

\subsection{Recovery and the Road to Resilience in Cedar Rapids}

In the aftermath of the 2008 flood, the city of Cedar Rapids responded by engaging the community over a 10-month planning process to develop a framework to not only recover from the flood, but to become resilient to future flooding. Beginning with a series of public open houses immediately following the flood, the city engaged the participation of over 1200 residents in a Neighborhood Planning Process (NPP), incorporated input from the US Army

${ }^{10}$ See the City of Cedar Rapids, Flood of 2008 Facts and Statistics: http://www.cedarrapids.org/discover_cedar_rapids/flood_of_2008/2008_flood_facts.php. 
Corps of Engineers (including a five-year feasibility study), and developed its own studies on the social and economic impacts from not investing in flood protection. ${ }^{11}$

The outcome of the initial public outreach was the Framework for Reinvestment and Revitalization, outlining a vision for Cedar Rapids as a "vibrant urban hometown - a beacon for people and businesses invested in building a greater community for the next generation." 12

At the core of the Framework was an extensive Flood Management System, envisioned to protect a stretch of 7.5 miles along the Cedar River. ${ }^{13}$ While the Corps study emphasized protecting the east side of the river, the city concluded from its own studies and from community feedback that it was important for any investment in flood resilience to protect both sides of the river.

The Flood Management System was projected to take 20 years to complete, at a cost of $\$ 375$ million. Ten years after the flood, the cost is currently estimated to be $\$ 550$ million. ${ }^{14}$ The key components of the Flood Management System include levees, (permanent and removable) walls, gates, and pump stations. The city also engaged in a land acquisition program, funded by federal grants, to protect land prone to flooding, largely on the west side of the river (Tate et al. [17]). Figure 4 illustrates the extent of the 2008 flood.

In addition, the Framework emphasized "the creation of Sustainable Neighborhoods," a concept that was subsequently fleshed out during the course of the NPP. The outcome of the NPP, the Neighborhood Reinvestment Plan, was approved by the City Council on May 13, 2009. The Neighborhood Reinvestment Plan emphasized neighborhood revitalization as another key component in addition to the flood-control infrastructure. ${ }^{15}$ The revitalization focused on ten neighborhoods, including Downtown, as well as the adjacent New Bohemia (NewBo) neighborhood and the historic Czech Village neighborhood across the river. Today, Czech Village, Downtown, and NewBo have become vibrant neighborhoods, attracting young professionals, entrepreneurs, and artists.

The City of Cedar Rapids committed to raising \$110 million on its own for the Flood Management System. As of July 5, 2018, the city had invested \$10 million of its total commitment; the state of Iowa had provided \$267 million; and \$14 million had been provided by federal grants. In addition, the US Army Corps of Engineers awarded \$17.4 billion for disaster recovery across the country, providing Cedar Rapids with $\$ 117$ million. ${ }^{16}$ The city has also raised funds from private donors and other local groups.

\footnotetext{
${ }^{11}$ See City of Cedar Rapids, Cedar River Feasibility Study: http://www.cedarrapids.org/discover_cedar_rapids/flood_of_2008/cedar_river_feasibility_study.php.

${ }^{12}$ See City of Cedar Rapids, Flood Recover Planning: http://www.cedar-rapids.org/local government/departments a f/community development/flood_recovery_planning.php.

${ }^{13}$ See City of Cedar Rapids, Flood Management System: http://www.cedar-

rapids.org/discover_cedar_rapids/flood_of_2008/flood_management_system.php.

${ }^{14}$ See The Gazette, July 5, 2018: https://www.thegazette.com/subject/news/government/cedar-rapids-flood-protection-funding-approvedarmy-corp-joni-ernst-iowa-2008-flood-20180706

${ }^{15}$ See City of Cedar Rapids, Neighborhood Reinvestment Action Plans: http://www.cedar-rapids.org/local_government/departments_a_ff/community_development/neighborhood_reinvestment_action_plans.php.

${ }^{16}$ See The Gazette, July 5, 2018: https://www.thegazette.com/subject/news/government/cedar-rapids-flood-protection-funding-approvedarmy-corp-joni-ernst-iowa-2008-flood-20180706
} 


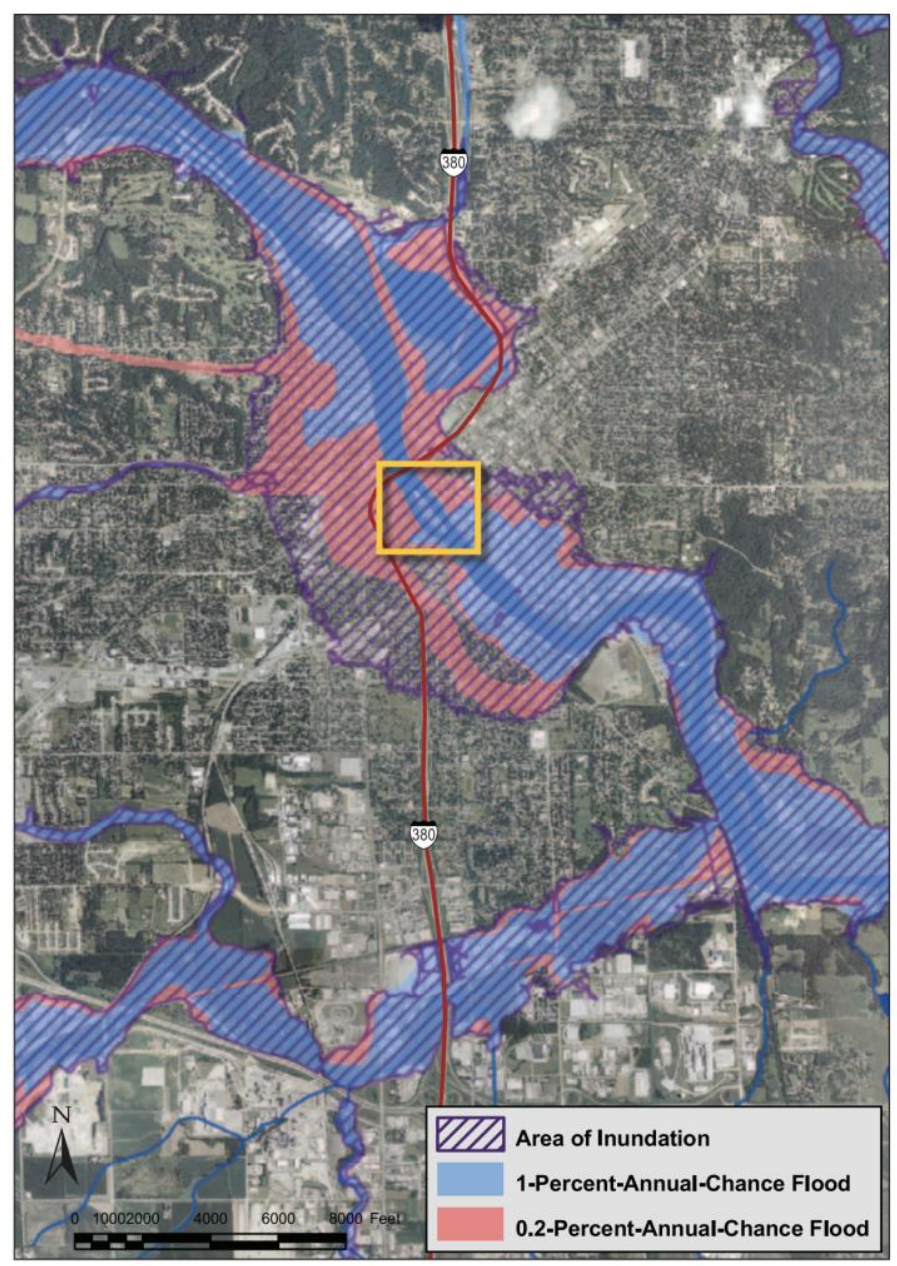

Figure 4. Extent of 2008 flood in Cedar Rapids, which exceed the 1-percent (100 year) and 0.2-percent (500 year) annual flood levels. Source: FEMA P-765 [15].

On September 27, 2016, the Cedar River crested at 22 feet (6.7 meters) following several days of heavy rain and flooding. The Flood of 2016 was the second biggest flood in Cedar Rapids. ${ }^{17}$ Fortunately, the city experienced little damage, especially compared to the 2008 flood. Although the Flood Management System was still a work in progress, the city was able to mobilize quickly to protect the river banks with 10 miles of sand and earthen barriers, at a cost of about $\$ 6$ million. While this temporary solution protected the city from the 2016 flood, it also increased the urgency for a true flood-control system: had the crest been anywhere near the 2008 levels, the city would have been devastated again.

\subsection{The 2008 Recession}

It should be noted that 2008 ushered in another major catastrophe, one that affected the entire country. The Great Recession, which is officially recognized as beginning on December 2007 and ending on June 2009, saw large declines in Gross Domestic Product (GDP), home prices, and stock markets, while unemployment rose to 10 percent by October $2009 .{ }^{18}$ Such added downward pressure on the local economy makes the path Cedar Rapids took seem even more

\footnotetext{
${ }^{17}$ Little Village Mag: https://littlevillagemag.com/facts-and-figures-cedar-rapids-flood-2016/.

${ }^{18}$ Federal Reserve History, The Great Recession: https://www.federalreservehistory.org/essays/great recession of 200709.
} 
impressive. While it is impossible to disentangle the effects of the recession from the effects of the flood, the impacts of reinvestment are expected to move in the opposite direction. Thus, they may be understated in the final CGE analysis.

\section{The Cedar Rapids CGE Models}

\subsection{The Local Economy}

Cedar Rapids is the largest city in, and the county seat of, Linn County, Iowa. Cedar Rapids is an integral part of a regional economy that includes the adjacent city of Marion, as well as the nearby cities of Hiawatha, Mount Vernon, and Robins, which together comprise the five most populous cities in Linn County. Given the close economic relationships between Cedar Rapids and the other cities in Linn County, this paper models the regional economy of Cedar Rapids as encompassing Linn County.

It should be noted that Linn County, along with Benton County to the west and Jones County to the east, comprise the Cedar Rapids Metropolitan Statistical Area (MSA), a much larger geographic region. For the purposes of this report, the relatively finer scale at the county level is more appropriate for analyzing impacts of investments by the city of Cedar Rapids.

Figure 5 presents select demographic and economic characteristics for the city of Cedar Rapids, from 2006 to 2015, as reported in the city's Comprehensive Annual Financial Report (CAFR) for Fiscal Year 2015. The city population has grown by almost 6000, while the median age has remained at around 36.

\begin{tabular}{|c|c|c|c|c|c|c|c|}
\hline \multicolumn{8}{|c|}{$\begin{array}{l}\text { Demographic and Economic Statistics } \\
\text { Last Ten Fiscal Years } \\
\text { (Unaudited) }\end{array}$} \\
\hline \multirow{2}{*}{$\begin{array}{c}\text { Fiscal } \\
\text { Year } \\
\text { Ended } \\
\text { June } 30\end{array}$} & \multirow[b]{2}{*}{ Population (1) } & \multirow{2}{*}{$\begin{array}{c}\text { Per } \\
\text { Household } \\
\text { Income (2) }\end{array}$} & \multirow{2}{*}{$\begin{array}{l}\text { Per Capita } \\
\text { Income (2) }\end{array}$} & \multirow{2}{*}{$\begin{array}{l}\text { Median } \\
\text { Age (2) }\end{array}$} & \multicolumn{2}{|c|}{ School Enrollment (3) } & \multirow{2}{*}{$\begin{array}{r}\text { Unemployment } \\
\text { Rate (4) }\end{array}$} \\
\hline & & & & & Public & Private & \\
\hline 2006 & 120,758 & 56,770 & 29,862 & 36.73 & 17,237 & 2,956 & 3.7 \\
\hline 2007 & 120,758 & 52,419 & 28,169 & 36.76 & 17,263 & 3,197 & 3.8 \\
\hline 2008 & 120,758 & 57,609 & 29,532 & 36.83 & 16,838 & 3,399 & 3.9 \\
\hline 2009 & 120,758 & 57,262 & 29,640 & 36.94 & 16,386 & 2,568 & 6 \\
\hline 2010 & 120,758 & 57,082 & 29,208 & 36.92 & 16,392 & 2,778 & 6.2 \\
\hline 2011 & 126,326 & 56,609 & 29,016 & 36.92 & 16,397 & 2,262 & 6.0 \\
\hline 2012 & 126,326 & 55,874 & 29,065 & 36.92 & 15,761 & 2,906 & 4.9 \\
\hline 2013 & 126,326 & 57,222 & 28,967 & 35.3 & 16,728 & 2,672 & 4.2 \\
\hline 2014 & 126,326 & 57,520 & 28,503 & 38 & 16,201 & 2,724 & 4.5 \\
\hline 2015 & 126,326 & 57,746 & 28,361 & 36.4 & 15,618 & 2,158 & 4.2 \\
\hline
\end{tabular}

Figure 5. Demographic and economic statistics for the city of Cedar Rapids. Source: Cedar Rapids CAFR, Fiscal Year 2015 (FY15).

Note the slow growth in household income and the trends in the unemployment rate reflect the impacts of the Great Recession. It is nevertheless noteworthy that the unemployment rate in Cedar Rapids as of June 30, 2015 was 4.2, a full percentage point lower than the national unemployment rate of 5.3. ${ }^{19}$

${ }^{19}$ See Bureau of Labor Statistics: https://data.bls.gov/timeseries/LNS14000000 


\subsection{Important Sectors}

Figure 6 presents the largest employers in the city of Cedar Rapids in 2015, and their relative share of county employment for both 2006 and 2015. Note that two hospitals (St. Luke's and Mercy), the Cedar Rapids Community School District, and the city itself, are some of the largest employers in the city.

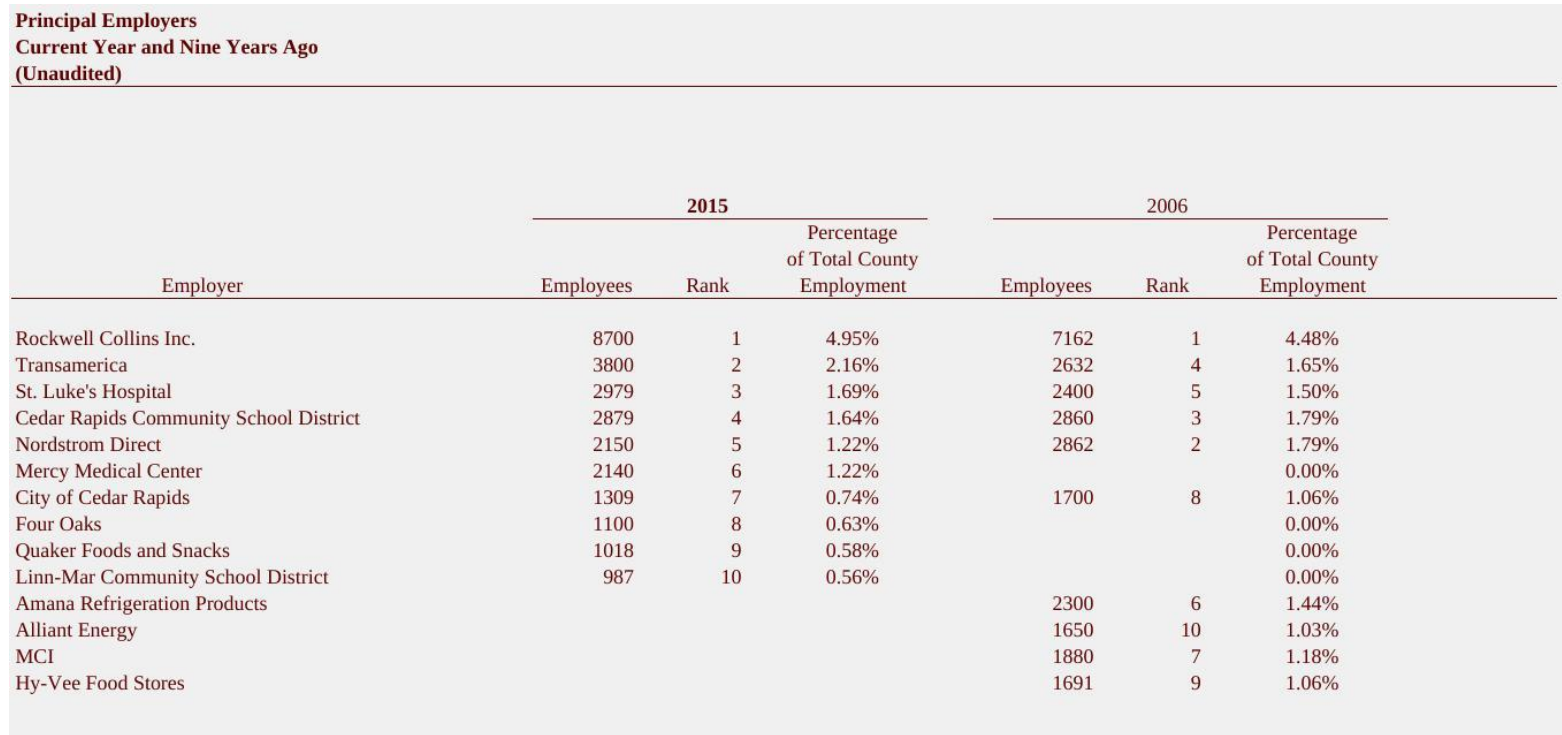

Figure 6. Principal employers in Cedar Rapids. Source: Cedar Rapids CAFR, FY15.

Rockwell Collins, an electronic equipment and design manufacturer that specializes in aerospace components, is the city's largest employer and accounts for nearly $5 \%$ of county employment. Historically, food processing (e.g., Quaker Oats and General Mills), paper manufacturing (e.g., International Paper), and transportation and logistics (e.g., CRST), have been some of the city's key industries. The city itself identified five "target industries" in developing a strategic economic development plan in 2014: ${ }^{20}$

- Life Sciences

- Logistics and Distribution

- Food Sciences and Processing

- Entrepreneurial Business Services, and

- Finance, Insurance, and Real Estate.

The CGE model presented in this report uses employment and wage data broken down by NAICS code. NAICS (North American Industry Classification System) codes are used to classify industries by their main activities. The high-level industries, and their corresponding two-digit NAICS codes, are given in Table 1.

Table 1. Two-digit NAICS codes and industries for 2017. Source: https://www.naics.com/search/.

${ }^{20}$ See City of Cedar Rapids, Economic Development: http://www.cedar-rapids.org/local_government/departments a f/community development/economic development services.phd 


\begin{tabular}{|l|l|}
\hline NAICS Code & Industry Title \\
\hline 11 & Agriculture, Forestry, Fishing and Hunting \\
\hline 21 & Mining \\
\hline 22 & Utilities \\
\hline 23 & Construction \\
\hline $31-33$ & Manufacturing \\
\hline 42 & Wholesale Trade \\
\hline $44-45$ & Retail Trade \\
\hline $48-49$ & Transportation and Warehousing \\
\hline 51 & Information \\
\hline 52 & Finance and Insurance \\
\hline 53 & Real Estate Rental and Leasing \\
\hline 54 & Professional, Scientific, and Technical Services \\
\hline 55 & Management of Companies and Enterprises \\
\hline 56 & Administrative and Support and Waste Management and Remediation Services \\
\hline 61 & Educational Services \\
\hline 62 & Health Care and Social Assistance \\
\hline 71 & Arts, Entertainment, and Recreation \\
\hline 72 & Accommodation and Food Services \\
\hline 81 & Other Services (except Public Administration) \\
\hline 92 & Public Administration \\
\hline
\end{tabular}

The data used for the CGE model includes 6-digit NAICS codes, which provide a much finer level of industry detail. Based on the city's own self-identified target industries, as well as on the industries that are important to downtown Cedar Rapids, the sectors in Table 2 and Table 3 were chosen to represent the Cedar Rapids regional economy. ${ }^{21}$

Table 2. Sectors in the Cedar Rapids CGE models that are not present in downtown Cedar Rapids.

\begin{tabular}{|l|l|}
\hline Sector name & NAICS Codes \\
\hline Electronics manufacturing & 33 \\
\hline Food processing & 31 \\
\hline Paper manufacturing & 32 \\
\hline All other manufacturing & $31-33$ \\
\hline Construction & 23 \\
\hline Transportation & 48,49 \\
\hline Online services & 45,49 \\
\hline Education & 61 \\
\hline Health care & 62 \\
\hline Wholesale trade & 42 \\
\hline Information & 51 \\
\hline Agriculture and mining & 11,21 \\
\hline Utilities & 22 \\
\hline
\end{tabular}

Note that manufacturing is broken down into four separate sectors: Electronics, Food, Paper, and All other manufacturing. Another key sector, Online services, include retail and logistics, reflecting the importance of online retailers (e.g., Nordstrom Direct in Fig. 5). Non retailoriented logistics are included in the Transportation sector. On the other hand, Construction,

${ }^{21}$ Some of these industries were emphasized during conversations with City officials. Helgeson et al. [1] discuss the value of informal data. 
Transportation, Education, Health care, Wholesale trade, Information, and Utilities are all as defined in Table 1. Moreover, Agriculture and mining are combined into a single sector due to their relatively small contribution to the local economy.

Table 3. Sectors in the Cedar Rapids CGE models that are present within and outside downtown.

\begin{tabular}{|l|l|}
\hline Sector name & NAICS Codes \\
\hline Financial and insurance services & 52 \\
\hline Real estate services & 53 \\
\hline Professional business services & 54,55 \\
\hline Services & 56,81 \\
\hline Arts and entertainment & 71 \\
\hline Accommodation & 72 \\
\hline Restaurants & 72 \\
\hline Retail & 44,45 \\
\hline
\end{tabular}

The sectors in Table 3 represent the core sectors in downtown Cedar Rapids. In the CGE model, these sectors are identified spatially by the location of the firm (i.e., whether or not the firm is located in downtown Cedar Rapids). Note that Professional business services (PBS) covers two NAICS sectors and reflects one of the city's target industries. Finally, Accommodation and Restaurants separated out of NAICS code 72.

\subsection{Downtown, NewBo, and Czech Village}

As discussed in Sec. 3.2, the city has invested in neighborhood revitalization in the aftermath of the 2008 floods. Downtown, NewBo, and Czech Village have been particular targets for commercial and residential development to attract a younger, more dynamic work force.

Figure 7 presents a map of the city of Cedar Rapids, highlighting the three neighborhoods of Downtown, NewBo, and Czech Village. Due to their size relative to the whole economy, the CGE model combines Downtown, NewBo, and Czech Village into a single spatial unit. For simplicity, the combined spatial unit is called "Downtown." 


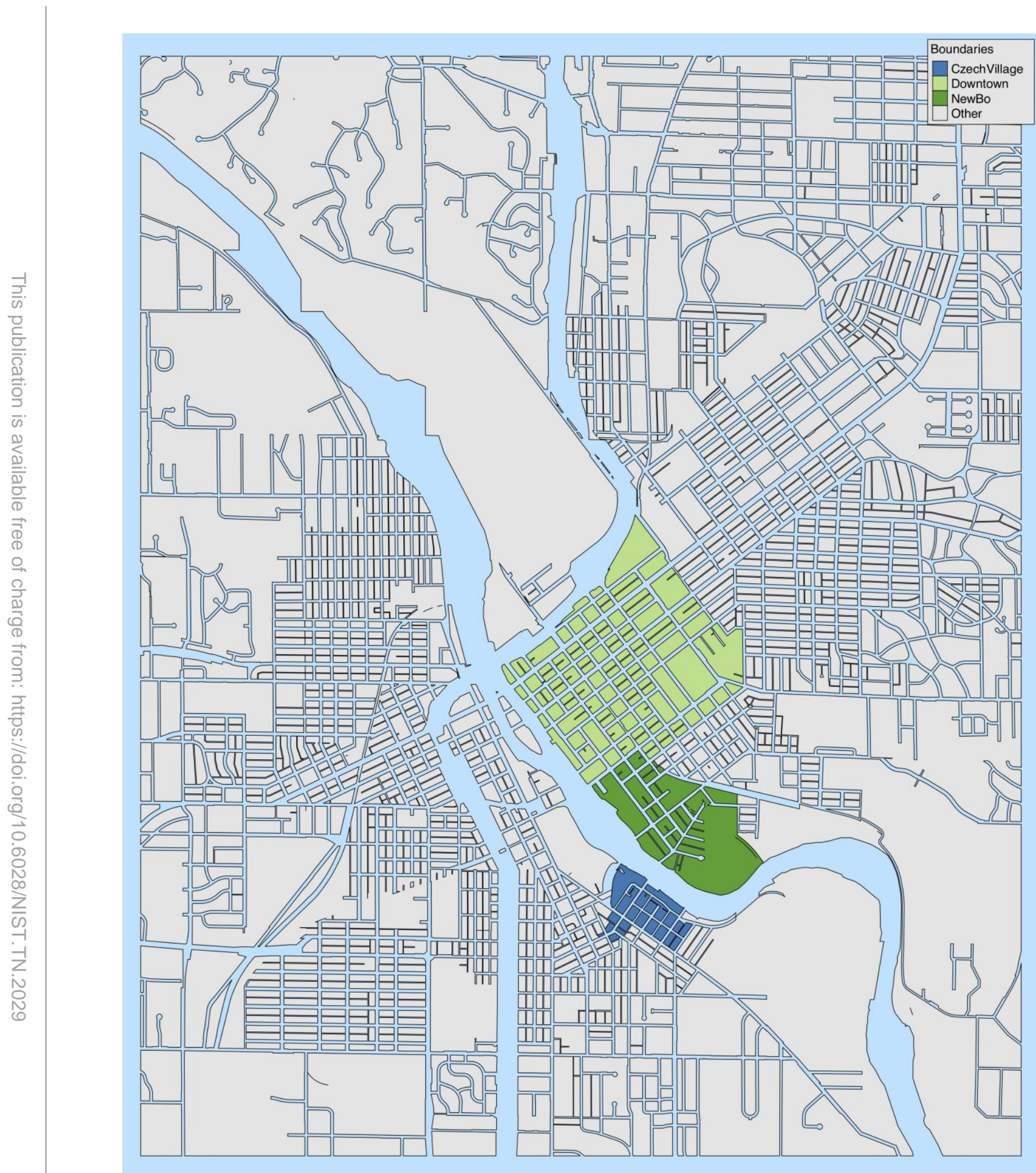

Figure 7. Detail of the "Downtown" area neighborhoods, with Czech Village and Downtown on the east side of the Cedar River and NewBo on the west. Map created using city of Cedar Rapids shapefiles (http://www.cedarrapids.org/local_government/departments_g_-_v/information_technology/available_gis_data.php). 


\subsection{Data Requirements and Other Details}

The foundation of a CGE model is the Social Accounting Matrix (SAM). The SAM can generally be described as "an organized matrix representation of all transactions and transfers between different production activities, factors of production, and institutions ... within the economy and with respect to the rest of the world" (Hirway et al. [18]). In other words, the SAM quantifies all cash flows between every agent in an economy. The SAM functions as the core of the CGE model, as it defines the base relationships between sectors, households, labor markets, and other key actors in the economy that the CGE model uses to determine the impacts of policies and shocks. Cutler et al. [19] provide a comprehensive discussion of methods for SAMs and CGE models.

Data requirements and sources for the SAM are discussed in detail in Helgeson et al. [1], Sec. 4. The CGE models presented in the current report use the construction of the SAM as outlined in Helgeson et al. [1], Sec. 5.1.

Once the SAM is constructed, it should be "balanced:" payments made by each component of the SAM should exactly equal payments received by each component of the SAM. For instance, total household expenditures should equal total household income (including any government transfers, rent receipts for land owned by households, and capital gains).

A balanced SAM is the main input to the CGE and represents the status quo for the economy. The model is "calibrated" when the CGE model equations solve for an equilibrium (set of prices and quantities that clear markets) that exactly reproduces the status quo. Once the CGE model is calibrated, it is ready for simulated shocks. Shocks are applied to exogenous parameters of the CGE model (e.g., total factor productivity) and a new equilibrium is found. Comparative static analysis compares the "status quo" equilibrium and the new equilibrium.

\section{Comparing Pre- and Post-2008 Cedar Rapids}

\subsection{Summary Statistics: 2007 and 2015}

This section presents select aggregate economic statistics that provide a snapshot of the Cedar Rapids regional economy in each of 2007 and 2015. Note that these are status quo outcomes in each model, rather than the results of a shock. In other words, these are "snapshots" of the pre-2008 economy and of the post-2008 economy. In future work, each model will receive the same shock (e.g., an increase in productivity) and each model's response to the shock will be compared as a way of quantifying the resilience dividend.

Table 4 presents land and capital values, as well as total acres, by District (i.e., Downtown, Czech Village, NewBo, and the rest of the county) for 2007 and 2015. Aside from Czech Village, which is much smaller than the other districts, the overall trend is growth in land and capital values between 2007 and 2015 .

The CGE models Czech Village, Downtown, and NewBo as a single "Downtown" unit. When these districts are combined, growth in the combined Downtown area is more pronounced: total capital values grow approximately $144 \%$ in the Downtown area (from $\$ 384.58$ million in 2007 to $\$ 824.64$ million in 2015), while capital values in the rest of the economy grow $83 \%$ (from $\$ 10.35$ billion to $\$ 18.95$ billion). Land values, on the other hand, only grow about $4.05 \%$ in the Downtown area (from $\$ 42.74$ million to $\$ 44.78$ million). In 
contrast, growth in land values for the rest of the economy is about $37 \%$ (from $\$ 2.74$ billion to $\$ 3.76$ billion).

Table 4. Land and capital values (in millions of dollars) and total acres by district and year, based on County Assessor data for Linn County, IA.

\begin{tabular}{|l|r|r|r|r|}
\hline District & Year & Land & \multicolumn{1}{|l|}{ Capital } & \multicolumn{1}{l|}{ Acres (Hectares) } \\
\hline CzechVillage & 2007 & 3.176 & 9.60 & $18.61(7.53)$ \\
\hline CzechVillage & 2015 & 1.216 & 9.26 & $39.76(16.09)$ \\
\hline Downtown & 2007 & 35.35 & 358.10 & $120.24(48.70)$ \\
\hline Downtown & 2015 & 38.70 & 757.29 & $300.48(121.60)$ \\
\hline NewBo & 2007 & 4.22 & 16.89 & $58.82(23.80)$ \\
\hline NewBo & 2015 & 4.60 & 58.09 & $137.03(55.45)$ \\
\hline Other & 2007 & 2739.99 & 10345.41 & $370559.25(149960.01)$ \\
\hline Other & 2015 & 3755.79 & 18948.89 & $498265.87(201641.04)$ \\
\hline
\end{tabular}

Total acreage in the combined Downtown area grew by a factor of 18 (from 197.67 to 3646.7). Acreage in the rest of the economy, on the other hand, only grew about $34 \%$ (from about 370 million to 498 million). Together with growth in capital, the growth in acreage reflects significant investment in developing Downtown relative to the rest of the economy.

Table 5 presents total employment and wages paid per worker for each year. While total employment in the Downtown area only grew by about $2.1 \%$ (compared to about $5.4 \%$ in the rest of the economy), wage per worker grew by $26.5 \%$ Downtown (compared to about $22.7 \%$ in the rest of the economy). Thus, while employment growth Downtown does not reflect the trend in capital and acreage, wage per worker does appear to be growing slightly faster in Downtown.

Table 5. Employment and (annual) wage per worker for the Downtown area (Czech Village, Downtown, and NewBo) and the rest of the regional economy by year, based on the Quarterly Census of Employment and Wages (QCEW) for the state of Iowa.

\begin{tabular}{|l|r|r|r|}
\hline District & Year & Employment & Wage per worker \\
\hline Downtown & 2007 & 5801 & 11244.89 \\
\hline Downtown & 2015 & 5924 & 14230.58 \\
\hline Other & 2007 & 115080 & 10556.87 \\
\hline Other & 2015 & 121296 & 12951.05 \\
\hline
\end{tabular}

It is worth noting that the comparison of pre- and post-2008 Cedar Rapids is not a comparative static analysis. Recall that comparative static analysis considers how some status quo economy responds to an exogenous shock. In contrast, the pre- and post-2008 Cedar Rapids models each serve as their own status quos. The goal in comparing them is to determine if pre-resilience Cedar Rapids responds differently to the same shock than postresilience Cedar Rapids. 


\section{Summary and Next Steps: Quantifying the Resilience Dividend}

\subsection{Summary}

The city of Cedar Rapids experienced extreme flooding in 2008. In response, the city has invested in becoming more resilient. This report presents Cedar Rapids as a case study for quantifying the resilience dividend. To that end, the report presents two CGE models of the Cedar Rapids economy: one for 2007, before the floods of 2008; the other for 2015, after the floods of 2008. The two models provide "snapshots" of the economy pre- and post-disaster and follow the methodology laid out in Helgeson et al. [1].

\subsection{Next Steps}

To quantify the resilience dividend, the 2007 model will serve as a kind of "counterfactual" to the 2015 model, in the sense that it can provide insight into how the economy would respond to shocks absent investment in resilience. For instance, how does an increase in productivity impact the economy that invested in resilience (the 2015 model) in contrast to the economy that did not invest in resilience (the 2007 model)? This work is ongoing. 


\section{Acknowledgments}

We are grateful to Sandi Fowler and Jeff Pomeranz (Cedar Rapids City Manager's Office), Donna Burkett and James Morris (Iowa Workforce Development), Mark Castenson (Linn County Assessor's Office) for invaluable information and insight, as well as David Butry (NIST), Stanley Gilbert (NIST), and Ken Harrison (NIST) for their comments.

\section{References}

[1] Helgeson J, Fung J, O'Fallon C, Webb D, Cutler H (2017) Identifying and Quantifying the Resilience Dividend using Computable General Equilibrium Models: A Methodological Overview. Proceedings of the $2^{\text {nd }}$ International Workshop on Modelling of Physical, Economic and Social Systems for Resilience Assessment, Vol. 1 (European Union, Luxembourg), pp 191-207.

[2] Shultz J, Elliott JR (2013) Natural Disasters and Local Demographic Change in the United States. Population and Environment 34(3):293-312.

[3] Kunreuther H, Michel-Kerjan E (2009) At War with the Weather (MIT Press, Cambridge, MA).

[4] Strömberg D (2007) Natural Disasters, Economic Development, and Humanitarian Aid. Journal of Economic Perspectives 21(3):199-222.

[5] Fung JF, Helgeson JF (2017) Defining the Resilience Dividend: Accounting for Cobenefits of Resilience Planning. NIST Technical Note 1959. https://dx.doi.org/10.6028/NIST.TN.1959.

[6] Rodin, J (2014) The Resilience Dividend: Being Strong in a World Where Things Go Wrong (PublicAffairs, New York).

[7] Gilbert SW, Butry DT, Helgeson J, Chapman R (2016) Community Resilience Economic Decision Guide for Buildings and Infrastructure Systems. NIST Special Publication 1197. https://dx.doi.org/10.6028/NIST.SP.1197.

[8] Helgeson JF, Grubb SA, Webb DH (2017) The Economic Decision Guide Software (EDGeS) Tool: User Guidance. NIST Special Publication 1214. https://dx.doi.org/10.6028/NIST.SP.1214.

[9] Tanner T, Surminski S, Wilkinson E, Reid RCJ, Rentschler JE, Rajput S (2016). The Triple Dividend of Resilience: Realising development goals through the multiple benefits of disaster risk management. (Global Facility for Disaster Reduction and Recovery (GFDRR) at the World Bank and Overseas Development Institute (ODI), London). http://www.odi.org/tripledividend.

[10] Mechler R, Mochizuki J, Hochrainer-Stigler S (2016). Disaster Risk Management and Fiscal Policy: Narratives, Tools, and Evidence Associated with Assessing Fiscal Risk and Building Resilience. Policy Research Working Paper; no. WPS 7635. (World Bank Group, Washington, DC).

[11] Bond CA, Strong A, Burger N, Weilant S (2017) Guide to the Resilience Dividend Valuation Model. (RAND Corporation, Santa Monica, CA). https://www.rand.org/pubs/research_reports/RR2130.html.

[12] Robinson, S, Kilkenny, M, \& Hanson, K (1990) The USDA/ERS computable general equilibrium (CGE) model of the United States., (AGES 9049).

[13] Bandara, SJ (1991) An investigation of "Dutch Disease" economics with a miniature CGE model'. Journal of Policy Modeling 13(1):67-92. 
[14] Pereira, A.M. and J.B. Shove (1988) Survey of dynamic computable general equilibrium models for tax policy evaluation. Journal of Policy Modeling, 10:401-436.

[15] United States. Federal Emergency Management Agency (2009). FEMA P-765:

Mitigation Assessment Team Report Midwest Floods of 2009 in Iowa and Wisconsin

Building Performance Observations, Recommendations, and Technical Guidance. (FEMA, Washington, DC)

[16] United States. Federal Emergency Management Agency (2008) FEMA DR-1763: Iowa Severe Storms, Tornadoes, and Flooding (DR-1763). (FEMA, Washington, DC)

[17] Tate, E, Strong, A, Kraus, T, \& Xiong, H (2016) Flood recovery and property acquisition in Cedar Rapids, Iowa. Natural Hazards, 80(3):2055-2079.

[18] Indira, H, Saluja, MR, \& Yadav, B (2008) The impact of public employment guarantee strategies on gender equality and pro-poor economic development. United Nations Development Programme Research Project, (34).

[19] Cutler, H, Davis, J, Hu, Y, Kakpo, K, Mckee, S, Shields, M and Zahran, S (2017) White Paper Developing a Methodology to Build Spatial SAMs and CGE Models., (Colorado State University, Fort Collins, CO). 